\title{
MODEL PENDIDIKAN HOLISTIK BERBASIS KARAKTER DI SEKOLAH KARAKTER INDONESIA HERITAGE FOUNDATION
}

\author{
Niya Yuliana ${ }^{1}$, M. Dahlan $\mathbf{R}^{2}$, Muhammad Fahri ${ }^{3}$ \\ Universitas Ibn Khaldun Bogor
}

\begin{abstract}
The destruction of the nation's character makes character education important in the current world of education. The development of character education is expected to be able to provide changes to the behavior of students. Therefore character education is not only a theory, but must be implemented in every activity, especially in school. In an effort to implement it, character education requires the right model to be applied in his life. One approach taken by the Indonesian Heritage Foundation (IHF) is to bring up the Character Based Holistic Education (PHBK) model. This study aims to describe a PHBK model that is successful in shaping children's character. This research is a type of field research with a qualitative approach. The data collection techniques using observations, interviews, and documentation to deepen data on research findings. The data analysis technique used is data reduction, data presentation, and conclusions used to process data in the discussion of research results. The results obtained in this study indicate that this model has succeeded in growing the character of children in IHF Character Primary Schools. In the teaching process, this model creates two forms of teaching, namely character education that is integrated with subjects, and specifically through the flow of character pillars.
\end{abstract}

Keyword: Holistic, Character, Education

\begin{abstract}
Abstrak: Rusaknya karakter bangsa menjadikan pendidikan karakter penting ditengah dunia pendidikan saat ini. Perkembangan pendidikan karakter diharapkan mampu memberikan perubahan terhadap tingkah laku pada peserta didik. Karena itu pendidikan karakter tidak hanya menjadi sebuah teori semata, melainkan harus terimplementasi di setiap kegiatan terutama di sekolah. Dalam upaya penerapannya, maka pendidikan karakter membutuhkan model yang tepat agar teraplikasikan dalam kehidupannya. Salah satu pendekatan yang dilakukan oleh lembaga Indonesia Heritage Foundation (IHF) adalah dengan memunculkan model Pendidikan Holistik Berbasis Karakter (PHBK). Penelitian ini bertujuan untuk memaparkan sebuah model PHBK yang berhasil dalam membentuk karakter anak. Penelitian ini merupakan jenis penelitian lapangan dengan pendekatan kualitatif. Adapun teknik pengumpulan data dengan menggunakan pengamatan, wawancara, dan dokumentasi guna memperdalam data hasil temuan penelitian. Teknik analisis data yang digunakan adalah reduksi data, penyajian data, dan kesimpulan yang digunakan untuk mengolah data pada pembahasan hasil penelitian. Hasil yang diperoleh dalam penelitian ini menunjukkan bahwa model ini telah berhasil dalam menumbuhkan karakter anak pada Sekolah Dasar Karakter IHF. Dalam proses pengajarannya, model ini menciptakan dua bentuk pengajaran yaitu pendidikan karakter yang terintegrasi dengan mata pelajaran, dan secara khusus melalui pengaliran pilar karakter.
\end{abstract}

Kata kunci: Holistik, Karakter, Pendidikan

\footnotetext{
${ }^{1}$ Universitas Ibn Khaldun Bogor, Email: niyayuliana45国gmail.com

${ }^{2}$ Universitas Ibn Khaldun Bogar, Email: dahlan国uika-bagar.ac.id

${ }^{3}$ Universitas Ibn Khaldun Bogar, Email: fahri国fai.uika-bogar.ac.id
} 


\section{PENDAHULUAN}

Pendidikan bukan hanya sekedar untuk mengembangkan potensi intelektualitas dan keterampilan peserta didik saja, akan tetapi pendidikan juga harus mampu menanamkan etika, dan akhlak yang baik dalam kehidupan ini. Pendidikan akan menjadi seimbang dan sesuai yang diharapkan apabila semua aspek lingkungan saling berhubungan serta bertanggung jawab dan berperan di dalamnya. Lingkungan tersebut meliputi keluarga, masyarakat, dan sekolah. Ketiga lingkungan ini memiliki keterikatan antara satu dengan yang lainnya, dengan kata lain setiap pembelajaran akan dipengaruhi oleh ketiga lingkungan ini (Dahlan, 2016, hlm. 49) agar dapat membentuk karakter peserta didik seutuhnya sesuai dengan UU No. 20 Tahun 2003 tentang Sistem Pendidikan Nasional Bab II Pasal 3, menyebutkan bahwa: "Tujuan pendidikan nasional adalah mengembangkan potensi peserta didik agar menjadi manusia yang beriman dan bertakwa kepada Tuhan Yang Maha Esa, berakhlak mulia, sehat, berilmu, cakap, kreatif, mandiri, dan menjadi warga negara yang demokratis serta bertanggung jawab (Sisdiknas No. 20 Tahun 2003, hlm. 3).

Pendidikan karakter tidak hanya berkaitan dengan masalah benar-salah, tetapi bagaimana menanamkan kebiasaan (habit) tentang hal-hal yang baik dalam kehidupan, sehingga peserta didik memiliki kesadaran, dan pemahaman yang tinggi, serta kepedulian dan komitmen untuk menerapkan kebajikan dalamkehidupan sehari-hari. Dengan demikian dapat dikatakan bahwa karakter merupakan sifat alami seseorang dalam merespons situasi secara bermoral, yang diwujudkan dalam tindakan nyata melalui perilaku baik, jujur, bertanggung jawab, hormat terhadap orang lain, dan nilai-nilai karakter mulia lainnya. Dalam konteks pemikiran islam, karakter berkaitan dengan iman dan ikhsan. Hal ini sejalan dengan ungkapan Aristoteles, bahwa karakter erat kaitannya dengan "habit" atau kebiasaan yang terus menerus dipraktikkan dan diamalkan (Mulyasa, 2011, hlm. 3).

Pendidikan karakter bertujuan untuk meningkatkan mutu proses dan hasil pendidikan yang mengarah pada pembentukan karakter dan akhlak mulia peserta didik secara utuh, terpadu, dan seimbang, sesuai dengan standar kompetensi lulusan pada setiap satuan pendidikan. Melalui pendidikan karakter peserta didik diharapkan mampu secara mandiri meningkatkan dan menggunakan pengetahuannya, mengkaji dan menginternalisasikan serta mempersonalisasikan nilai-nilai karakter dan akhlak mulia sehingga terwujud dalam perilaku sehari-hari (Mulyasa, 2011, hlm. 9).

Dalam Islam terdapat tiga nilai utama, yaitu akhlak, adab, dan keteladanan. Akhlak merujuk kepada tugas dan tanggung jawab selain syari'ah dan ajaran Islam secara umum. Sedangkan adab merujuk kepada sikap yang dihubungkan dengan tingkah laku yang baik. Dan keteladanan merujuk pada kualitas karakter yang ditampilkan oleh seorang muslim yang baik dan mengikuti keteladanan Nabi Muhammad SAW. Ketiga nilai inilah yang menjadi pilar pendidikan karakter dalam Islam (Majid \& Andayani, 2011, hlm. 58). Islam mengajarkan kehidupan yang dinamis dan progresif dengan senantiasa mengembangkan kepedulian sosial, menghargai waktu, bersikap terbuka, demokratis, berorientasi pada kualitas, egaliter, kemitraan, anti-feodalistik, mencintai kebersihan, mengutamakan persaudaraan, berakhlak mulia dan sikapsikap positif lainnya dalam makna yang sederhana (Dahlan, 2018, hlm. 298).

Implementasi pendidikan karakter telah dicontohkan oleh kepribadiannya Rasullullah $S A W$ dalam kehidupannya sehari-hari yang memiliki nilai-nilai akhlak yang terpuji serta mulia. Banyak sekali sifat Rasullulah yang patut untuk ditiru sebagai bagian dari pendidikan 
karakter yang secara garis besar ia berikan kepada umatnya seperti shiddiq, amanah, tabligh, fathonah. Keempat kepribadian Rasulullah tersebut merupakan pondasi utama yang akan membentuk kepribadian seorang muslim yang seutuhnya.

Namun realita yang terjadi di dunia pendidikan saat ini tidak bisa dipungkiri bahwa sejak dulu hingga saat ini dan zaman yang akan datang, salah satu problematika yang hangat di dunia pendidikan ialah karakter. Karakter merupakan persoalan yang besar dan paling darurat dalam suatu negara. Indonesia belum mempunyai pendidikan karakter yang efektif untuk menjadikan bangsa Indonesia yang berkarakter (tercermin dari tingkah lakunya). Padahal ada beberapa mata pelajaran yang berisikan pesan-pesan moral, misalnya pelajaran agama, kewarganegaraan dan Pancasila. Namun proses pembelajaran yang dilakukan adalah dengan pendekatan pengahafalan (kognitif) saja. Dengan itu para murid diharapkan dapat menguasai materi yang keberhasilannya diukur hanya dengan kemampuan anak menjawab soal ujian yang orientasinya semata-mata hanyalah untuk memperoleh nilai bagus.

Pendidikan karakter saat ini amat mendesak dan perlu mendapatkan perhatian langsung dari negara. Melihat kondisi fakta yang terjadi, sekolah-sekolah saat ini sangat marak terjadinya aksi peningkatan tawuran antar-pelajar, kekerasan, pemerkosaan, pembunuhan, narkoba, dan bentuk-bentuk kenakalan remaja lainnya. Bahkan yang paling memprihatinkan adalah pada saat Ujian Nasional (UN), nilai-nilai kejujuran sudah dihilangkan dari diri siswa itu sendiri. Bahkan ada beberapa sekolah dan para guru terlibat melakukan kecurangan pada saat UN berlangsung, dan ini merupakan salah satu problematika yang sampai saat ini belum mendapatkan pemecahan masalahnya (Dharma dkk., 2011, hlm. 16).

Problematika pendidikan karakter di Indonesia saat ini dikarenakan tiga hal, pertama adalah hilangnya karakter dan kepribadian islami dalam dirinya. Kedua, guru mengajarkan pendidikan karakter namun masih seputar teori dan konsep saja, belum sampai pada ranah tahapan aplikasi dalam kehidupan sehari-hari. Ketiga, kurangnya model atau contoh yang tepat dalam penerapan pendidikan karakter di setiap sekolah. Maka tidak heran jika karakter yang dimiliki bangsa Indonesia semakin hari semakin merosot. Jika penyebab masalahnya seperti itu, apa dan bagaimanapun upaya pemerintah untuk mengembalikan karakter anak bangsa dan menciptakan generasi terbaik akan menjadi sia-sia jika tidak adanya keseimbangan antara konsep, teori dan model yang nyata dalam pengimplementasiannya di sekolah.

Dengan demikian, untuk membuat pendidikan karakter di Indonesia menjadi lebih efektif dan teraplikasikan di setiap sekolah, maka ibu Ratna Megawangi mendirikan Indonesia Heritage Foundation (IHF) dengan memunculkan ide untuk membuat sesuatu yang baru dalam memperbaharui penerapan pendidikan karakter di Indonesia saat ini agar lebih dapat dipahami para pendidik maupun peserta didik dengan mengembangkan model Pendidikan Holistik Berbasis Karakter (PHBK). IHF telah menjalankan sebuah model pendidikan karakter secara komprehensif yaitu model PHBK yang dapat membentuk karakter siswa.

Tujuan penelitian ini diharapkan agar dapat membuka paradigma berpikir para guru tentang model pendidikan holistik bahwa dengan model tersebut mampu menciptakan anak-anak yang inovatif, kreatif, dan pembelajar sejati.

\section{TINJAUAN PUSTAKA}

\begin{tabular}{rrr}
\multicolumn{2}{r}{ Pendidikan } & merupakan sebagai \\
usaha untuk & membina
\end{tabular} mengembangkan pribadi manusia, aspek rohaniah dan jasmaniah, juga harus berlangsung secara bertahap. Oleh karena itu, suatu kematangan yang bertitik akhir pada optimalisasi perkembangan atau pertumbuhan baru dapat tercapai bilamana 
berlangsung melalui proses demi proses ke arah tujuan akhir perkembangan atau pertumbuhannya (Arifin, 2012, hlm. 13).

Istilah karakter secara harfiah berasal dari bahasa Latin "character", yang antara lain berarti : watak, tabiat, sifat-sifat kejiwaan, budi pekerti, kepribadian, atau akhlak. Adapun secara istilah, karakter diartikan sebagai sifat manusia pada umumnya, dimana manusia mempunyai banyak sifat yang tergantung dari faktor kehidupannya sendiri. Karakter adalah sifat kejiwaan, akhlak atau budi pekerti yang menjadi ciri khas seseorang atau sekelompok orang. Karakter merupakan nilai-nilai perilaku manusia yang berhubungan dengan Tuhan Yang Maha Esa, diri sendiri, sesama manusia, lingkungan, dan kebangsaan yang terwujud dalam pikiran, sikap, perasaan, perkataan, dan perbuatan berdasarkan norma-norma agama, hukum, tata krama, budaya, dan adat istiadat (Musfah, 2012, hlm. 44-45). Menurut (Suyanto, 2010, hlm. 34) karakter adalah cara berpikir dan berperilaku yang menjadi ciri khas tiap individu untuk hidup dan bekerjasama, baik dalam lingkup keluarga, masyarakat, bangsa dan negara. Individu yang berkarakter baik adalah individu yang bisa membuat keputusan dan siap mempertanggung jawabkan tiap akibat dari keputusan yang ia buat.

Pendidikan karakter adalah sebuah usaha untuk mendidik anak-anak agar dapat mengambil keputusan dengan bijak dan mempraktikannya dalam kehidupan sehari-hari, sehingga mereka dapat memberikan kontribusi yang positif kepada lingkungan. Nilai-nilai karakter yang perlu ditanamkan kepada anak-anak adalah nilai-nilai universal dimana seluruh agama, tradisi, dan budaya pasti menjunjung tinggi nilai-nilai tersebut (Megawangi, 2016, hlm. 113). Sedangkan menurut (Dharma dkk, 2011, hlm. 5) pendidikan karakter ialah usaha untuk mendidik peserta didik agar dapat mengambil keputusan dengan bijak dan mempraktikannya dalam kehidupan sehari- hari, sehingga mereka dapat memberikan kontribusi yang positif kepada lingkungannya.

Kata "holistik" (holistic) berasal dari kata "holisme" (holism). Kata 'holisme' pertama kali diperkenalkan pada tahun 1926 oleh Jan Smuts, seorang negarawan dari Afrika Selatan, dalam bukunya yang berjudul Holism and Evolution. Asal kata 'holisme' diambil dari bahasa Yunani, holos, yang berarti semua atau keseluruhan. Holisme adalah suatu pemikiran yang menyatakan bahwa sistem alam semesta, baik yang bersifat fisik, kimiawi, hayati, sosial, ekonomi, mental-psikis, dan kebahasaan, serta segala kelengkapannya harus dipandang sebagai sesuatu yang utuh dan bukan merupakan kesatuan dari bagianbagian yang terpisah (Wikipedia, 2019).

Pendidikan holistik merupakan suatu filsafat pendidikan yang berangkat dari pemikiran bahwa pada dasarnya seorang individu dapat menemukan identitas, makna, dan tujuan hidup melalui hubungannya dengan masyarakat, lingkungan alam, dan nilai-nilai spiritual. Secara historis, pendidikan holistik sebenarnya bukan hal yang baru. Strategi ini selalu mengalami revolusi perkembangan dan saat ini membawa banyak kemajuan menakjubkan di berbagai sekolah-sekolah Eropa dan Asia yang berkembang (Rubiyanto \& Haryanto, 2010, hlm. 32). Pendidikan holistik adalah pendidikan yang bertujuan memberi kebebasan peserta didik untuk mengembangkan diri tidak hanya secara intelektual saja, akan tetapi juga memfasilitasi perkembangan jiwa dan raga secara keseluruhan sehingga tercipta manusia Indonesia yang berkarakter kuat yang mampu mengangkat harkat bangsa dengan mewujudkan manusia merdeka (Rubiyanto \& Haryanto, 2010, hlm. 1)

\section{METODOLOGI PENELITIAN}

Penelitian ini merupakan jenis penelitian lapangan (field research), dengan pendekatan kualitatif. Metode 
penelitian ini digunakan untuk memaparkan bagaimana bentuk model pendidikan holistik berbasis karakter (PHBK) dalam upaya penanaman karakter siswa di Sekolah Karakter Indonesia Heritage Foundation (IHF). Penelitian ini dimulai pada tanggal 3 Januari 2019 sampai dengan 4 Maret 2019 yang dilaksanakan Sekolah Dasar Karakter Indonesia Heritage Foundation (IHF) yang terletak di Jl. Raya Jakarta Bogor Km. 31 No. 46 Cisalak, Cimanggis Kota Depok. Sumber data yang dibutuhkan dalam penelitian ini adalah pihak yang bersangkutan yaitu Direktur sekolah karakter IHF, kepala sekolah dasar karakter IHF, dan para guru yang mengajar di sekolah dasar karakter sebagai sumber informasi yang dicari tentang model pendidikan holistik berbasis karakter (PHBK) serta peluang dan tantangan di sekolah karakter IHF. Dan data sekunder adalah sumber data yang dijadikan penunjang dalam pokok bahasan berupa buku penunjang dan data hasil observasi lingkungan yang berhubungan dengan fokus penelitian. Semua data tersebut diharapkan mampu memberikan gambaran dan pemahaman tentang model pendidikan holistik berbasis karakter (PHBK) di SD Karakter IHF. Adapun teknik dalam pengumpulan data melalui pengamatan, wawancara, dan dokumentasi agar memperoleh hasil temuan yang mendalam. Teknik analisis data dengan melakukan reduksi data, penyajian data sehingga dapat ditarik kesimpulan.

\section{HASIL PENELITIAN DAN PEMBAHASAN \\ 1. Pendidikan Holistik Berbasis Karakter (PHBK)}

Persoalan karakter bangsa

menjadikan negeri ini berada dalam krisis multidemensional. Krisis multidimensional adalah suatu situasi dimana bangsa dan negeri ini sedang dilanda oleh berbagai macam pertentangan besar maupun kecil dan berbagai keruwetan di bidang politik, ekonomi, sosial, dan juga kebobrokan moral (Momonika, 2014). Artinya bangsa ini akan menuju jurang kehancuran jika dibiarkan terus menerus. Rendahnya kredibilitas Indonesia di mata dunia internasional merupakan cerminan dari perilaku individu-individu yang tidak berkarakter, sehingga berdampak negatif terhadap pengelolaan negara, korporasi, sistem hukum, yang akhirnya akan menurunkan daya saing Indonesia menjadi terpuruk secara sosial, ekonomi, dan budaya (Megawangi, 2016, hlm. 7). Kemudian disusul juga dengan sumberdaya manusia (SDM) yang sangat rendah.

Pemerintah Indonesia memberikan perhatian besar terhadap pendidikan, dengan dibangunnya sekolah-sekolah dari tingkat dasar sampai perguruan tinggi, dengan kurikulum, metode, dan sistem hampir lima tahun sekali mengalami perubahan. Bahkan untuk memajukan proses pendidikan, pemerintah telah mengeluarkan anggaran yang sangat besar dari APBN. Agar tujuan pendidikan nasional bisa terwujud dengan maksimal (Dahlan, 2015, hlm. 56). Fakta di lapangan yang terjadi bahwa dunia pendidikan saat ini hanya membangun aspek kognitifnya saja, bahkan hampir tidak ada aplikasi dalam penerapan pendidikan karakter, sehingga dalam membangun karakter (character building) tidak memiliki titik temu yang menjadi solusi bagi pendidikan karakter. Padahal pendidikan karakter adalah pendidikan yang membangun dan menanamkan nilai-nilai karakter pada anak sehingga dirinya mampu menjadi problem solver bagi lingkungan sekitar.

Lahirnya sebuah gagasan tentang pendidikan karakter menjadi sebuah alasan setelah melihat proses yang dihasilkan dalam dunia pendidikan belum menciptakan manusia yang berkarakter. Kondisi tersebut di buktikan dengan perilaku dan moral para remaja bangsa Indonesia yang semakin rusak. Hal itu dapat dilihat pada kondisi saat ini yang marak dengan aksi tawuran antar pelajar, 
narkoba, seks bebas, dan kenakalan remaja lainnya yang sulit dikendalikan. Permasalahan pendidikan karakter saat ini perlu mendapatkan respon dari berbagai pihak yang terkait terutama pihak yang menyelenggarakan pendidikan. Setelah melihat rusaknya moral bangsa Indonesia, maka perlu adanya solusi sebagai upaya mengembalikan karakter bangsa Indonesia agar solusi tersebut mudah di implementasikan dalam dunia pendidikan.

Indonesia belum mempunyai pendidikan karakter yang efektif untuk menjadikan bangsa yang berkarakter dengan tercermin dari tingkah lakunya. Padahal ada beberapa mata pelajaran yang berisikan pesan-pesan moral, misalnya pelajaran agama, kewarganegaraan dan Pancasila. Namun proses pembelajaran yang dilakukan adalah dengan pendekatan penghafalan yang mengarah pada kemampuan secara kognitif semata. Para murid tersebut hanya diharapkan dapat menguasai materi yang keberhasilannya diukur hanya dengan kemampuan anak menjawab soal ujian. Karena orientasinya hanya untuk memperoleh nilai bagus, maka pelajaran tersebut tidak akan berdampak kepada perubahan perilaku siswa. sehingga yang terjadi kesenjangan antara pengetahuan moral (cognition) dan perilaku (action) (Megawangi, 2016, hlm. 92). Semisal setiap orang mengetahui bahwa mencontek adalah perbuatan salah dan melanggar ketentuan, akan tetapi banyak sekali siswa yang tetap melakukannya. Problematika tersebut menjadi dasar pembuktian bahwa terdapat kesenjangan antara pengetahuan yang dimiliki dengan tindakan. Hal tersebut menjadi perhatian para pakar pendidikan untuk memberikan solusi yang nyata dalam memperbaiki karakter bangsa, terutama di Indonesia.

Membangun kembali karakter baik seseorang bukanlah hal yang mudah, berdasarkan hasil wawancara dengan Direktur Sekolah Karakter mengemukakan bahwa bangsa Indonesia mengalami degradasi moral yang menyebabkan terjadinya kerusuhan pada tahun 1998. Salah satu tokoh pemerhati pendidikan karakter menjadi terpacu untuk melakukan perbaikan terhadap bangsanya dengan digagasnya sebuah model pendidikan yang akan mampu mengembalikan karakter bangsa Indonesia yaitu Ibu Dr. Ir. Ratna Megawangi, M.Sc, Ph.D. Beliau merupakan seorang Dosen IPB yang melanjutkan post-doctoral di Tufts University, Massachussets Amerika Serikat dengan memfokuskan penelitiannya pada family and child development yang penelitiannya ini terkait pada pengembangan keluarga, anak, karakter, dan hal-hal yang berhubungan tentang anak dan keluarga. Dengan pengetahuan yang dimilikinya, maka beliau tertarik untuk memperbaiki karakter bangsa setelah melihat rusaknya karakter bangsa Indonesia. Model pendidikan yang digagas Ibu Ratna Megawangi ialah sebuah model Pendidikan Holistik Berbasis Karakter (PHBK), model PHBK merupakan model pendekatan yang di percaya bahwa karakter seseorang dapat terbentuk dengan baik.

Secara historis, model pendidikan holistik sebenarnya bukan suatu hal yang baru, beberapa tokoh klasik yang dianggap sebagai perintis pendidikan holistik, diantaranya: Jean Rousseau, Ralp Waldo Emerson, Henry Thoreau, Bronson Alcott, Johann Pestalozzi, Friedrich Froebel, dan Fransisco Ferrer. Selain itu, terdapat pula tokoh lain yang dianggap sebagai pendukung pendidikan holistik, yaitu Rudolf Steiner, Maria Montessori, Francis Parker, John Dewey, John Caldeww Holt, George Dennison, Kieran Egan, Howard Gardner, Jiddu Khrinamurti, Carl Jung, Abraham Maslow, Carl Rogers, Paul Goodman, Ivan Illich, dan Paulo Freire (Rubiyanto \& Haryanto, 2010, hlm. 32).

Model Pendidikan Holistik Berbasis Karakter adalah salah satu program yang digaungkan oleh lembaga Indonesia Heritage Foundation (IHF) yang diyakini dapat mengembalikan karakter bangsa Indonesia. Model PHBK merupakan 
sebuah filosofi pendidikan yang percaya bahwa setiap manusia dapat menjadi insan berkarakter, cerdas, kreatif, pembelajar sejati serta dapat menemukan identitas, makna dan tujuannya hidupnya. Tujuan model Pendidikan Holistik Berbasis Karakter adalah membentuk manusia secara utuh (holistik) yang berkarakter, yaitu mengembangkan aspek fisik, emosi, sosial, kreatifitas, spiritual, dan inteletual siswa secara optimal, serta membentuk manusia yang life long leaners (pembelajar sejati) (Muslich, 2011, hlm. 33).

Beberapa hasil penelitian menunjukkan bahwa ada kaitan erat antara keberhasilan pendidikan karakter dengan keberhasilan akademik, serta perilaku prososial anak, sehingga dapat membuat suasana sekolah dapat begitu menyenangkan dan kondusif untuk proses belajar mengajar yang efektif (Megawangi, 2016, hlm. 43). Pendidikan karakter akan menjadi sebuah teori jika tidak dipahami secara utuh dalam pandangan kurikulum pendidikan nasional (Muslich, 2011, hlm. 70). Artinya, pendidikan karakter tidak hanya sebagai wacana dalam dunia pendidikan. Tetapi menjadi sebuah bentuk yang direalisasikan oleh sekolah melalui pengajaran guru di kelas.

IHF mengharuskan bagi para guru yang akan mengajar di Sekolah Karakter untuk mengikuti pelatihan terlebih dahulu. Karena IHF menginginkan bahwa tidak hanya siswa saja yang diajarkan nilai-nilai karakter, akan tetapi juga nilai-nilai karakter harus terbentuk lebih dahulu dalam diri gurunya. Di pelatihan ini, para guru akan diberitahukan terlebih dahulu mengenai model PHBK, dan bentukbentuk pengajaran yang digunakan agar dapat menciptakan suasana belajar yang menyenangkan dan juga memberikan rasa aman, sehingga guru mampu membangun karakter positif siswa. Pendidikan karakter menekankan berbagai aspek potensi manusia, yaitu aspek fisik, aspek akademik, aspek sosial dan budaya, aspek kreatifitas, aspek spiritual, dan aspek emosi. Semua aspek tersebut menjadi dasar bahwa setiap anak memiliki kebaikan yang tertanam sehingga dalam upaya membentuk karakter baik, maka aspek tersebut harus dikembangkan.

Dalam proses pengajarannya, model Pendidikan Holistik Berbasis Karakter di SD Karakter menggunakan dua bentuk pengaliran karakter yang dilakukan agar pendidikan karakter terinternalisasi dalam diri anak, yaitu dengan pengaliran secara formal (pengaliran pilar-pilar karakter) dan pengaliran secara non-formal (terintegrasi dengan mata pelajaran).

Pengaliran karakter secara formal yaitu dengan memfokuskan anak agar memahami makna dan tujuan dari setiap nilai-nilai karakter yang diajarkan. Lickona juga menjelaskan bahwa pendidikan karakter tidak hanya sekedar dipahami sebagai pengetahuan kognitif saja (moral knowing), tetapi juga harus dirasakan dan disadari bahwa nilai-nilai karakter itu penting (moral feeling), kemudian di implementasikan dalam kehidupan sehari-hari hingga dirinya terbiasa melakukan hal-hal kebaikan (moral action).

Khusus kurikulum 9 Pilar karakter, pola pengajarannya adalah student active learning dimana anak dilibatkan aktif dalam diskusi maupun dalam aktifitas. Guru lebih ditekankan untuk bertanya kepada anak, dan anak lebih aktif untuk memberikan jawaban dan komentar. Filosofi dari cara ini adalah bahwa fungsi pendidikan adalah "to bring forth" (mengaktualkan dari dalam diri anak) (Megawangi, 2016, hlm. 156). Pengaliran pilar karakter dilakukan di pagi hari dengan durasi waktu 15-20 menit dalam pengaliran pilar karakter. Waktu refleksi ini memberikan kesempatan kepada para siswa agar mengekspresikan secara verbal pengetahuan mereka, kecintaan/perasaan, dan bagaimana tindakan yang dilakukan dalam kehidupannya. Pengajaran 9 pilar karakter ditambah K4 dilakukan selama setahun sekolah, dimana setiap pilar diajarkan setiap dua atau tiga minggu sekali sesuai dengan base on case, artinya 
pilar karakter akan dibahas sesuai waktu yang ditentukan. Adapun pilar-pilar karakternya yaitu:

1. Cinta Tuhan dan segenap ciptaan-Nya

2. Mandiri, disiplin, tanggung jawab

3. Jujur, amanah, dan berkata bijak

4. Hormat, santun, dan pendengar yang baik

5. Dermawan, suka menolong, dan kerja sama

6. Percaya diri, kreatif, dan pantang menyerah

7. Pemimpin yang baik dan adil

8. Baik dan rendah hati

9. Toleran, cinta damai, dan bersatu.

Selanjutnya pengaliran karakter secara non-formal yaitu terintegrasi dengan mata pelajaran. Artinya, pendidikan karakter tidak hanya menjadi tanggung jawab mata pelajaran Agama dan (PKn) Pendidikan Kewarganegaraan semata. Dalam proses pelaksanaannya, nilai-nilai karakter harus di integrasikan ke dalam setiap mata pelajaran dan juga pada setiap pokok bahasan yang ada di sekolah. Dengan terintegrasi, pendidikan karakter menjadi tanggung jawab seluruh komponen yang ada di sekolah. Berdasarkan hasil wawancara dari beberapa informan sebelumnya, pola penerapan pendidikan karakter secara terintegrasi dengan mata pelajaran, antara lain dengan menyebutkan nilai-nilai karakter yang terkandung di dalamnya, mengintegrasikan nilai-nilai karakter secara langsung ke dalam mata pelajaran, dimasukkan ke dalam soal-soal yang diberikan oleh guru, ketika memberikan pujian, menggunakan perumpamaan dengan kejadian-kejadian yang dialami siswa, menggunakan cerita untuk memunculkan nilai-nilai karakternya, mengintegrasikan nilai-nilai karakter dengan menggunakan kegiatan-kegiatan seperti bakti sosial, field trip, home visit, outbond, dan kegiatan-kegiatan yang berpotensi memunculkan nilai-nilai kemanusiaan.

Keberhasilan dari sebuah model pendidikan holistik berbasis karakter dalam membentuk karakter sudah terlihat dalam diri anak yang mengekspresikannya melalui tingkah lakunya. Ketika di kelas, anak mampu menghormati temannya, menghargai perbedaan yang ada, perkataannya santun ketika bertemu dengan orang lain, berani bertanya tentang sesuatu yang ia ingin ketahui, mau meminta maaf ketika melakukan kesalahan, menjadi problem solver bagi sekitarnya. Ketika di luar kelas, anak-anak ramah terhadap lingkungan artinya mampu menjaga kebersihan dengan membuang sampah pada tempatnya, mentaati peraturan yang ada seperti meletakkan sepatu pada lemarinya, dan lain sebagainya. Ini membuktikan bahwa dengan model PHBK ini karakter anak dapat terbentuk dan tentu dengan proses pembelajaran yang memberikan rasa aman dan menyenangkan bagi anak.

\section{Peluang dan Tantangan Model Pendidikan Holistik Berbasis Karakter (PHBK)}

Dalam penerapan model pendidikan holistik berbasis karakter menjanjikan peluang dan tantangan bagi pembentukan karakter anak. Di satu sisi, dunia teknologi yang semakin canggih dan terus berkembang pesat menjadi tuntutan bagi sekolah untuk mempersiapkan generasigenerasi yang unggul dalam segala bidang. maka yang diperlukan adalah manusiamanusia yang kreatif dan berdaya pikir tinggi. Dalam upaya menyiapkan manusiamanusia yang berkompeten tentunya melalui pengalaman belajar yang menyenangkan.

Indonesia saat ini sedang menghadapi dua tantangan besar, yaitu desentralisasi atau otonomi daerah yang saat ini sudah dimulai, dan era globalisasi total akan terjadi pada tahun 2020 (Muslich, 2011, hlm. 35). Solusi untuk menghadapi tantangan tersebut ialah mempersiapkan sumberdaya manusia (SDM) yang berkualitas, kreatif, dan mampu berpikir tingkat tinggi. Dalam hal pengembangan SDM, pendidikan memiliki 
nilai strategis dan mempunyai peran penting sebagai suatu investasi di masa depan. Karena secara teoritis, pendidikan adalah dasar dari pertumbuhan ekonomi, dasar dari perkembangan sains dan teknologi, mengurangi kemiskinan dan peningkatan kualitas peradaban manusia pada umumnya (Dahlan, 2015, hlm. 57)

Sekolah memang berperan dalam menyiapkan manusia-manusia yang unggul, akan tetapi hal tersebut juga membutuhkan berbagai pihak yang mendukung serta menunjang dalam membentuk karakter anak adalah peran orang tua siswa. Peran orang tua dalam memberikan pemahaman kepada anak mengenai pendidikan karakter harus dipahami secara utuh, sebagaimana yang dijelaskan oleh Ratna Megawangi bahwa segala perilaku orang tua dan pola asuh yang diterapkan di dalam keluarga pasti berpengaruh dalam pembentukan kepribadian atau karakter seorang anak (Megawangi, 2016, hlm. 74). Di zaman modern ini, para orang tua sering gagal dalam membentuk karakter anak-anaknya, sehingga pendidikan karakter di sekolah adalah solusi yang tepat, apalagi kalau anak-anak tidak mendapatkan pendidikan karakter di rumahnya. Masa kanak-kanak banyak dihabiskan di sekolah, dan apa yang terekam dalam memori anak-anak mengenai pengalaman di sekolah akan mempengaruhi kepribadian anak ketika dewasa (Megawangi, 2016, hlm. 90).

Untuk itu penanaman nilai karakter tidak hanya dalam pelajaran tertentu saja, melainkan harus terintegrasi dengan setiap mata pelajaran, dan di setiap kegiatan anak di sekolah. Pembentukan karakter itu tentunya dengan menggunakan pendekatan yang memang dikhususkan untuk fokus dalam pengembangan karakter. Oleh sebab itu, model pendidikan holistik berbasis karakter digagas karena memang diyakini bahwa model ini dapat membangun karakter positif anak untuk mempersiapkan generasi-generasi yang unggul.
Proses pembentukan karakter memiliki tantangan tersendiri dalam pelaksanaannya terutama dalam penggunaan modelnya apakah sesuai atau tidak. Model PHBK di Sekolah Karakter menjadi model yang digaungkan oleh IHF, dengan peluncuran model tersebut yang telah diuji coba melalui SBB telah dipercaya bahwa karakter positif anak dapat terbangun. Tapi di sisi lain, model PHBK ini juga memiliki tantangan dalam penerapannya. Tantangan utama model pendidikan holistik berbasis karakter (PHBK) adalah ketika proses pelaksanaannya tidak sejalan antara visi dan misi sekolah dengan orang tua, sehingga perilaku yang dimunculkan anak kadang tidak sesuai dengan apa yang di inginkan oleh sekolah. Misalnya ketika pengaliran pilar karakter di sekolahnya tentang mandiri, anak diberikan pengetahuan, pemahaman, dan aktifitas yang dikerjakannya harus secara mandiri. Tetapi ketika di rumah, hal-hal yang bisa dikerjakan anak terutama untuk dirinya sendiri ternyata masih dibantu oleh orang tuanya ataupun pengasuhnya, dan anggota keluarga lainnya. Hal ini yang menjadi sulit dalam pembentukan karakter anak dengan cepat.

Para orang tua memiliki cara tersendiri dalam proses pengajarannya, artinya setiap orang tua menginginkan anaknya yang terbaik dalam segala hal. Jika peran orang tua tidak mampu memberikan contoh keteladanan yang baik bagi anaknya, maka pendidikan karakter di sekolah akan sia-sia. Padahal menurut Thomas Lickona dalam membentuk karakter anak harus menekankan tiga komponen karakter yang baik (components of good character) yaitu moral knowing atau pengetahuan tentang moral, moral feeling atau perasaan tentang moral, dan moral action atau perbuatan bermoral.

Akan tetapi, sejak awal pihak sekolah sudah melakukan sosialisasi kepada calon orang tua yang mendaftar di SD Karakter. Pada tahapan ini, orang tua diberikan pemahaman mengenai 
pendidikan karakter yang ditanamkan di SD Karakter dan bagaimana metode yang digunakan dalam pengajarannya. Jika orang tua sepakat dengan visi dan misi sekolah karakter, maka tahap selanjutnya adalah proses penerimaan anak sebagai siswa baru kemudian dilanjutkan pada tahap trial. Trial akan dilakukan sebanyak dua kali, yang pertama anak akan diamati kegiatannya selama di Sekolah Karakter, yang kedua anak dicoba untuk menjalani aktifitas sehari-hari di Sekolah Karakter. Setelah resmi diterima sebagai siswa, para orang tua kembali diberikan pengarahan mengenai pendidikan karakter yang ingin ditanamkan di sekolah melalui pengaliran 9 Pilar Karakter dan K4, metode pengajaran pendidikan karakter, serta urgensi pendidikan karakter saat ini.

\section{KESIMPULAN}

Model pendidikan holistik berbasis karakter (PHBK) merupakan sebuah filosofi pendidikan yang percaya bahwa setiap manusia dapat menjadi insan berkarakter, cerdas, kreatif, pembelajar sejati serta dapat menemukan identitas, makna dan tujuannya hidupnya. Dengan 2 bentuk pengajaran yaitu: terintegrasi dengan mata pelajaran serta kegiatan proses pembelajaran, dan secara khusus melalui pengaliran Pilar Karakter yang dilakukan sebelum pembelajaran selama 15-20 menit. Adapun peluang yang dimiliki model ini cukup besar, karena belum ada model pendidikan yang tepat dalam penerapan pendidikan karakter sehingga model ini dipilih dan diyakini dapat membentuk karakter anak. Sedangkan tantangannya ialah setiap orang tua pasti memiliki model pengasuhan tersendiri, artinya karakter anak akan sulit terbentuk jika tidak sejalan antara pengasuhan orang tua dengan sekolah.

\section{DAFTAR PUSTAKA}

Arifin, M. (2012). Filsafat Pendidikan Islam (12 ed.). Jakarta: Bumi Aksara.
Dahlan, M. (2015). Membangun Manusia Berkualitas Melalui Pendidikan. Jurnal Pendidikan Agama Islam Fikrah, 58.

Dahlan, M. (2016). Konsep Pembelajaran Aqidah Akhlak (1 ed.). Yogyakarta: Deepublish.

Dahlan, M. (2018, Desember 12). Relevansi Pemahaman Agama dengan Interaksi Sosial Siswa. Penamas, 31.

Dharma, dkk. (2011). Pendidikan Karakter: Kajian Teori dan Praktik di Sekolah (1 ed.). Bandung: Remaja Rosdakarya.

Majid, A., \& Andayani, D. (2011). Pendidikan Karakter Perspektif Islam (1 ed.). Bandung: Remaja Rosdakarya.

Megawangi, R. (2016). Pendidikan Karakter: Solusi yang Tepat untuk Membangun Bangsa (5 ed.). Depok: Indonesia Heritage Foundation.

Momonika. (2014, 12 9). Brainly. Dipetik 3 4, 2019, dari http://brainly.co.id

Mulyasa, E. (2011). Manajemen Pendidikan Karakter (1 ed.). Jakarta: Bumi Aksara.

Musfah, J. (2012). Pendidikan Holistik (1 ed.). Jakarta: Kencana Prenada Media.

Muslich, M. (2011). Pendidikan Karakter: Menjawab Tantangan Krisis Multidimensional (2 ed.). Jakarta: Bumi Aksara.

Rubiyanto, N., \& Haryanto, D. (2010). Strategi Pembelajaran Holistik di Sekolah (1 ed.). Jakarta: Prestasi cc. (2010). Model Pembinaan Pendidikan Karakter di Lingkungan Sekolah (1 ed.). Bandung: Remaja Rosdakarya.

Undang-Undang Republik Indonesia. Sisdiknas No. 20 Tahun 2003.

Wikipedia. (2019). Ensiklopedia Bebas. Dipetik Februari 24, 2019, dari Ensiklopedia Bebas: https://id.wikipedia.org/wiki/Holism e 